\title{
Overlapping expression patterns and differential transcript levels of phosphate transporter genes in arbuscular mycorrhizal, $P_{\mathrm{i}}$-fertilised and phytohormone-treated Medicago truncatula roots
}

\author{
Ulf Grunwald $\cdot$ Wenbing Guo $\cdot$ Kerstin Fischer $\cdot$ Stanislav Isayenkov $\cdot$ \\ Jutta Ludwig-Müller · Bettina Hause $\cdot$ Xiaolong Yan $\cdot$ Helge Küster $\cdot$ Philipp Franken
}

Received: 21 October 2008 / Accepted: 10 December 2008 / Published online: 24 January 2009

(C) Springer-Verlag 2009

\begin{abstract}
A microarray carrying 5,648 probes of Medicago truncatula root-expressed genes was screened in order to identify those that are specifically regulated by the arbuscular mycorrhizal (AM) fungus Gigaspora rosea, by $\mathrm{P}_{\mathrm{i}}$ fertilisation or by the phytohormones abscisic acid and jasmonic acid. Amongst the identified genes, $21 \%$ showed a common induction and $31 \%$ a common repression between roots fertilised with $\mathrm{P}_{\mathrm{i}}$ or inoculated with the AM fungus G. rosea, while there was no obvious overlap in the expression patterns between mycorrhizal and phytohormonetreated roots. Expression patterns were further studied by comparing the results with published data obtained from roots colonised by the AM fungi Glomus mosseae and Glomus intraradices, but only very few genes were identified as being commonly regulated by all three AM fungi. Analysis of $\mathrm{P}_{\mathrm{i}}$ concentrations in plants colonised by either
\end{abstract}

Electronic supplementary material The online version of this article (doi:10.1007/s00425-008-0877-z) contains supplementary material, which is available to authorized users.

\section{U. Grunwald}

Max-Planck Institute for Terrestrial Microbiology,

Karl-von-Frisch-Strasse, 35043 Marburg, Germany

W. Guo $\cdot$ K. Fischer $\cdot$ P. Franken $(\varangle)$

Institute of Vegetable and Ornamental Crops,

Theodor-Echtermeyer-Weg, 14979 Grossbeeren, Germany

e-mail: Franken@igzev.de

S. Isayenkov $\cdot$ B. Hause

Department of Secondary Metabolism,

Leibniz Institute of Plant Biochemistry,

POB 110432, 06018 Halle, Germany

J. Ludwig-Müller

Institute for Botany, Technische Universität Dresden,

Zellescher Weg 20b, 01062 Dresden, Germany of the three AM fungi revealed that this could be due to the higher $\mathrm{P}_{\mathrm{i}}$ levels in plants inoculated by $G$. rosea compared with the other two fungi, explaining that numerous genes are commonly regulated by the interaction with $G$. rosea and by phosphate. Differential gene expression in roots inoculated with the three AM fungi was further studied by expression analyses of six genes from the phosphate transporter gene family in M. truncatula. While MtPT4 was induced by all three fungi, the other five genes showed different degrees of repression mirroring the functional differences in phosphate nutrition by G. rosea, G. mosseae and $G$. intraradices.

Keywords Abscisic acid - Arbuscular mycorrhiza . Gigaspora rosea - Glomus intraradices - Glomus mosseae . Jasmonic acid $\cdot$ Phosphate transporter genes

\section{H. Küster}

Institute for Genome Research and Systems Biology,

Center for Biotechnology, Bielefeld University,

33594 Bielefeld, Germany

W. Guo $\cdot$ X. Yan

Root Biology Centre, South China Agricultural University, 510642 Guangzhou, China

S. Isayenkov

Biology Department, University of York,

Area 9, York YO10 5DD, UK 


$\begin{array}{ll}\text { Abbreviations } \\ \mathrm{ABA} & \text { Abscisic acid } \\ \mathrm{AM} & \text { Arbuscular mycorrhizal } \\ \mathrm{Gi} & \text { Glomus intraradices } \\ \mathrm{Gm} & \text { Glomus mosseae } \\ \mathrm{Gr} & \text { Gigaspora rosea } \\ \mathrm{JA} & \text { Jasmonic acid } \\ \mathrm{P}_{\mathrm{i}} & \text { Inorganic phosphate }\end{array}$

\section{Introduction}

Fungi of the phylum Glomeromycota form mutualistic symbioses with $80 \%$ of the vascular land plants, called arbuscular mycorrhizas (Newman and Reddell 1987; Schüßler et al. 2001). This widespread interaction is in the first instance characterised by nutrient exchange between the two partners (Smith and Read 1997). Arbuscular mycorrhizal (AM) fungi deliver mineral nutrients to the plant and obtain as heterotrophic organisms carbohydrates from their autotrophic partner (Smith and Read 1997). This is the general concept of the mycorrhizal symbiosis, but the extent of exchange can vary depending on fungal and plant species (Smith et al. 2003; Lerat et al. 2003). In addition to being biofertilisers, AM fungi possess bioregulating activities by changing the content and distribution of phytohormones (Ludwig-Muller 2000; Hause et al. 2007). This has been shown in different plant AM fungus combinations, but the role of AM fungi as bioregulators was only comprehensively analysed in the case of jasmonic acid (JA) and abscisic acid (ABA). Both, JA and ABA, are important for mycorrhizal establishment as shown by a reverse genetics approach diminishing JA biosynthesis (Isayenkov et al. 2005) or by use of an ABA-deficient mutant (Herrera-Medina et al. 2007), respectively. Moreover, for JA it has been demonstrated that the up-regulation of biosynthesis takes place in arbuscule-containing plant cells of M. truncatula (Isayenkov et al. 2005). The third important function of the AM symbiosis is based on its influence on plant responses to their biotic and abiotic environment. In most cases, mycorrhizal roots show enhanced resistance to pathogens (Borowicz 2001) and AM fungi confer tolerance to the plant under adverse soil conditions such as drought (Ruiz-Lozano 2003) or heavy metal contamination (Gohre and Paszkowski 2006).

For more than a decade, the AM symbiosis has also been a subject of molecular studies. Expression analyses using targeted and non-targeted approaches were carried out to gain insights into the processes underlying the development and the different functions of the symbiosis (Balestrini and Lanfranco 2006). A number of plant genes were identified which were known from other interactions showing similarities between the colonisation of the plant by mycorrhizal fungi, by pathogens or nodule-forming rhizobia (e.g. Gianinazzi-Pearson et al. 1996; van Rhijn et al. 1997). This obvious overlap has not only been used to discuss the evolution of plant-microbe interactions (Parniske 2000), but also to explain the role of AM fungi as bioprotectors (Grunwald et al. 2004; Li et al. 2006). However, most of the studies were conducted to understand the molecular basis of nutrient transport from the fungus to the plant. In this respect, mycorrhiza-regulated phosphate transporter $(P T)$ genes were isolated and analysed in different plants (Rausch et al. 2001; Harrison et al. 2002). Interestingly, in the legumes Lotus japonicus and Medicago truncatula down-regulation or mutations of LjPT3 and MtPT4 led to a reduction in mycorrhization (Maeda et al. 2006; Javot et al. 2007), while such a phenotype could not be observed with LePT4 indicating functional redundancy of $P T$ genes in tomato (Nagy et al. 2005).

A broad overview of gene expression patterns in mycorrhiza has been obtained from large array analyses in the model plant $M$. truncatula and Oryza sativa. AM fungi of the genus Glomus were used in most cases and the results were compared with expression profiles in roots after fertilisation with inorganic phosphate $\left(\mathrm{P}_{\mathrm{i}}\right)$, in nodules or during pathogenic interactions (Liu et al. 2003; Manthey et al. 2004, Hohnjec et al. 2005; Guimil et al. 2005). In order to extend knowledge about gene regulation in the AM symbiosis, the analysis for the present paper was extended to the interaction between Gigaspora rosea and M. truncatula. The fungus G. rosea differs in various aspects from Glomus species. It contains no RNA during dormancy, it only infects the plant through germinating spores, it reacts differently to compounds occurring in root exudates and it forms auxiliary cells (Franken and George 2006). However, diversity of the AM symbiosis has not only been observed for morphological aspects. AM fungi also seem to differ in the amounts of phosphate transferred to the plant (Smith et al. 2004) and in their response to phosphate enrichments in the soil (Cavagnaro et al. 2005). To gain a deeper insight into these mechanisms, the expression of the $M$. truncatula phosphate transporter gene family (five known genes and one newly identified) was analysed in roots colonised with the three AM fungi $G$. mosseae, G. intraradices and $G$. rosea. In addition, transcript levels were monitored not only after $P_{i}$ fertilisation, but also after treatment of the roots with $\mathrm{ABA}$ or $\mathrm{JA}$, in order to identify genes which are not directly regulated by the AM fungus, but indirectly by changes in the levels of these phytohormones. The results were compared with those obtained in this study for G. rosea and with results published for two Glomus species (Hohnjec et al. 2005). 


\section{Materials and methods}

Plant growth and inoculation

Medicago truncatula cv. Jemalong A17 (seeds obtained from Thierry Huguet, CNRS-INRA Toulouse, France) was cultivated as described by Wulf et al. (2003). Briefly, seeds were subjected to a 10 min treatment with sulphuric acid and three times washing in sterile water, followed by $3 \mathrm{~min}$ sterilization in sodium hypochlorite $(1.6 \%, \mathrm{w} / \mathrm{v})$ and a final washing step in sterile water. Surface-sterilised seeds were germinated on wet filter paper in a Petri dish in the dark for 3 days at $4^{\circ} \mathrm{C}$ and for additional $2-4$ days at RT. Seedlings were transferred to pots containing 0.71 of a $1: 1$ mixture of vermiculite and expanded clay and grown at $25^{\circ} \mathrm{C}$ with $16 \mathrm{~h}$ light and $65 \%$ humidity. Plants were fertilised every 4 days with $10 \mathrm{ml}$ Long Ashton nutrient solution (Hewitt 1966) containing reduced $P_{i}$ concentration $(0.13 \mathrm{mM})$.

In order to obtain mycorrhizal roots, inoculation was carried out by $1: 10$ mixing of commercial available inoculum of Gigaspora rosea BEG9, Glomus mosseae BEG12 or Glomus intraradices BEG141 (Biorize Sarl, Dijon, France) with the substrate when transplanting to pots. Plants were harvested 6 weeks after inoculation and mycorrhiza parameters were estimated after trypan blue staining according to the method of Trouvelot et al. (1986). For the $+\mathrm{P}$ treatment, plants were fertilised during the whole growth period with the fertiliser solution containing $1.3 \mathrm{mM} \mathrm{P}_{\mathrm{i}}$. In order to challenge the plants with the phytohormones, $100 \mu \mathrm{M}(+)$ cis, trans-abscisic acid in $10 \mathrm{ml} 2.5 \%$ acetone or $45 \mu \mathrm{M}$ jasmonic acid in the $0.13 \mathrm{mM} \mathrm{P}_{\mathrm{i}}$ fertiliser solution were applied to the growth substrate $4 \mathrm{~h}$ before harvest. Control plants received the same amount of the corresponding solvents in the $0.13 \mathrm{mM} \mathrm{P} \mathrm{P}_{\mathrm{i}}$ fertiliser solution.

\section{Array hybridisation}

Plant material was frozen and grinded in liquid nitrogen. For each RNA extraction, $100 \mathrm{mg}$ of grinded plant material was processed with the RNeasy kit according to the protocol of the supplier (Qiagen, Hilden, Germany). DNA was removed by DNase I treatment (Bauer et al. 1993) and RNA quality and quantity was estimated with the Lab Chip-System RNA 600 Nano kit in the Bioanalyzer 2100 (Agilent Technologies, Boeblingen, Germany). Mycorrhiza-regulated gene expression was confirmed by cDNA synthesis (procedure see below) and non-quantitative PCR using primer pairs for MtPT4 (Table S1 in Supplementary material) and MtHAl (Krajinski et al. 2002). For hybridisation of the Mt6kRIT macro- and microarrays, cDNA probes were synthesised from two biological replicates with each two technical repetitions and labelled with ${ }^{33} \mathrm{P}, \mathrm{Cy} 3-$ or Cy5-dUTP (Amersham, Freiburg, Germany), respectively
(Küster et al. 2004). Hybridisation signals were obtained using the Storm Phosphoimager (Molecular Dynamics, Ismaning, Germany) equipped with the ImageQuant software or by the ScanArray 4000 microarray scanner (PerkinElmer, Boston, MA, USA), and the data were statistically analysed using the EMMA 1.0 software (Dondrup et al. 2003).

\section{PCR cloning}

mRNA sequences from the phosphate transporter genes MtPT1-5 were obtained from the NCBI database (AF000354, AF000355, EF016358, AY116210, EF016359). The gene MtPT6 was deduced from two cDNA sequences (TC99939, BQ145041) and one genomic sequence (clone MTH2-177C12 on chromosome 3). Using the primers MtPT6for, MtPT6rev and MtPT6-5' (Table S1 in Supplementary material), cDNA fragments were amplified, sequence analysed and the complete coding sequence was assembled. The whole MtPT6 cDNA sequence has been submitted to the EMBL database and can be obtained under the AC number AM982728. Amino acid sequences were deduced from the coding regions and aligned with a selection of phosphate transporters from other plants and from the AM fungus Glomus versiforme as outgroup by ClustalW (Thompson et al. 1994). The amino acid alignment was phylogenetically analysed by the program PUZZLE (version 4.0.2; Strimmer and von Haeseler 1996) and the results were displayed as dendrogram with the program TREEVIEW (version 1.5.3; Page 1996).

\section{Real-time PCR}

RNA was extracted and DNase treated as described above. cDNA was synthesised from $4 \mu \mathrm{g}$ total RNA in a volume of $20 \mu \mathrm{l}$ using oligo(dT) following the protocol of the MMLVreverse transcriptase supplier (Promega, Mannheim, Germany). The absence of contamination with genomic DNA was confirmed by PCR using primer pairs spanning an intron sequence as described (Wulf et al. 2003). Realtime PCR reactions were carried out in $25 \mu \mathrm{l}$ volume using $2 \mu \mathrm{l}$ of cDNA (1:10 diluted, three technical repetitions) as template, $0.15 \mu \mathrm{M}$ primer pairs of the MtPT genes (Table S1 in Supplementary material) or of the MtTefl gene (Wulf et al. 2003) and the QuantiTect ${ }^{\mathrm{TM}} \mathrm{SYBR}^{\circledR}$ Green PCR Kit (Qiagen, Hilden, Germany). For the standard curve, a dilution series of $10^{8}$ to 10 molecules of the different gene fragments was prepared by PCR and checked by agarose gel electrophoresis. Detection of the amplified fragments and recording of the melting curve was done on an iCycler (Bio-Rad Laboratories, München, Germany) with $15 \mathrm{~min}$ at $95^{\circ} \mathrm{C}$ and 45 cycles $\left(15 \mathrm{~s}\right.$ at $95^{\circ} \mathrm{C} ; 30 \mathrm{~s}$ at $56^{\circ} \mathrm{C} ; 30 \mathrm{~s}$ at $72^{\circ} \mathrm{C}$ ) followed by heating from 56 to $95^{\circ} \mathrm{C}$ with a rate of 
$0.5^{\circ} \mathrm{C}$ per $10 \mathrm{~s}$. The melting curve indicated the specificity of the primer pairs. The copy number was calculated with the computer program iCycler iQ-System Vers. 2.1.A (Bio$\mathrm{Rad})$. All reactions were performed with three biological replicates in three technical repetitions each.

Concentration of $\mathrm{P}_{\mathrm{i}}$

For soluble $\mathrm{P}_{\mathrm{i}}$ concentration measurements, $100 \mathrm{mg}$ fresh shoot material (four biological repetitions) were sampled and macerated in $1.2 \mathrm{ml}$ extraction buffer $(45 \mathrm{mmol} / \mathrm{l}$ sodium acetate buffer, $\mathrm{pH}$ 5.0). The suspension was centrifuged at $12,000 \mathrm{~g}$ for $30 \mathrm{~min}$ at $4^{\circ} \mathrm{C}$ and $\mathrm{P}_{\mathrm{i}}$ concentration was determined by carrying out the phosphorus-molybdate blue colour reaction and measuring absorbance at $700 \mathrm{~nm}$ (Murphy and Riley 1962).

\section{Results and discussion}

Gigaspora rosea-regulated transcript levels

Medicago truncatula roots inoculated with the AM fungus Gigaspora rosea and harvested 6 weeks after inoculation showed in two independent experiments a mycorrhizal colonisation degree of 37 and $41 \%$ and a relative arbuscule frequency of 80 and $82 \%$, respectively. The arbuscules resembled the Arum-type. This pattern has been already described before in the interaction between $M$. truncatula and $G$. rosea, but is different from the type found in tomatoG. rosea mycorrhizas (Burleigh et al. 2002). Non-quantitative RT-PCR showed that the AM-specific genes MtHAl (Krajinski et al. 2002) and MtPT4 (Harrison et al. 2002) were clearly expressed in the roots colonised by G. rosea, but not in the controls (data not shown). Screening of the Mt6kRIT microarray with cDNA probes from mycorrhizas and controls resulted in significant expression values for 1,300 genes (Table 1). For 118 genes a significant up-regulation between 2- and 20-fold could be detected, while 222 were up to 25-fold repressed (Table S2a in Supplementary material). This was much less than the number of Glomus intraradices-regulated genes identified amongst the same set of cDNA fragments (Manthey et al. 2004), but in that study, $P<0.075$ and $M \geq 0.7$ or $\leq-0.7$ were accepted as being significant. Based on the same values, only slightly higher percentages between 12 and $20 \%$ were obtained in another experiment where the regulation by the AM fungi Glomus mosseae and G. intraradices was analysed on Mt16kOLI1 microarrays of $M$. truncatula (Hohnjec et al. 2005). Far fewer genes (4\%) were detected in an experiment with Glomus versiforme, although inserts of a cDNA library from $M$. truncatula mycorrhizal roots were hybridised (Liu et al. 2003). Significant signals for the
Table 1 Overview of array screening results

\begin{tabular}{llll}
\hline Samples & $\begin{array}{l}N \text { genes } \\
(P<0.05)\end{array}$ & $\begin{array}{l}N \text { induced } \\
\text { genes } \\
(M \text { value })\end{array}$ & $\begin{array}{l}N \text { repressed } \\
\text { genes }(M \text { value })\end{array}$ \\
\hline G. rosea & 1,300 & $118(4.31 \geq M)$ & $222(-4.64 \leq M)$ \\
ABA & 1,202 & $121(3.32 \geq M)$ & $205(-4.17 \leq M)$ \\
JA & 433 & $193(4.86 \geq M)$ & $71(-4.29 \leq M)$ \\
$\mathrm{P}_{\mathrm{i}}$ & 1,221 & $139(3.9 \geq M)$ & $143(-4.65 \leq M)$ \\
\hline
\end{tabular}

The number of genes which gave significant results after hybridisation of different samples versus control is shown

The numbers of at least two fold induced or repressed genes ( $\log 2$ ratio $M \geq 1$ and $\leq-1$ ) and the maximum and minimum $M$ values are indicated

AM-specific genes MtPT4 and MtHAl could not be detected on the arrays, although they are induced in G. rosea-colonised roots. This has been also observed in other array hybridisation experiments (Liu et al. 2003, 2007) and is probably due to the low overall expression of these genes.

Data for $G$. rosea from the analysis presented here were compared with those for G. mosseae and G. intraradices previously published (Hohnjec et al. 2005). This revealed 163 genes with significant results for all three fungi (Table S3 in Supplementary material), whereof 57 genes are regulated by G. rosea (Table 2). Amongst the 163 genes, which could be compared between the three fungi, $7 \%$ showed an overlapping pattern of regulation between $G$. rosea- and G. mosseae- and $9 \%$ between G. rosea- and G. intraradices-colonised roots, but $22 \%$ were similarly up- or downregulated in mycorrhiza of the two Glomus species in the study of Hohnjec et al. (2005). Most of the eight genes commonly up- or down-regulated in mycorrhiza of all three AM fungi are of unknown function but one putatively encodes an alpha-xylosidase precursor (Table 2). Interestingly, a common regulation pattern for Glomus- and Gigaspora-mycorrhizal roots has been shown for a xyloglucan endotransglucosylase gene, which is also involved in modification of xyloglucan polymers (Maldonado-Mendoza et al. 2005). A more recent analysis compared expression patterns in M. truncatula mycorrhiza with a Glomus and a Gigaspora species using the Mt16kOLI1 and $10 \%$ of the $G$. intraradices-induced genes were also regulated in roots colonised by Gigaspora gigantea (Liu et al. 2007). This is more close to the $9 \%$ we have found between G. rosea and $G$. intraradices than to the $22 \%$ identified as overlapping between the two Glomus species. Much more genes with overlapping expression were found in an investigation, where 10 out of 14 selected genes showed a common induction in M. truncatula mycorrhiza formed by different AM fungal isolates (Massoumou et al. 2007). However, the genes were pre-selected as mycorrhiza-regulated, and the 
Table 2 Clusters,

annotations and $M$ values of $G$. rosea-regulated genes

\begin{tabular}{|c|c|c|c|c|}
\hline Cluster & Description & $\mathrm{Gr}$ & $\mathrm{Gm}$ & $\mathrm{Gi}$ \\
\hline \multicolumn{5}{|l|}{ Cell wall } \\
\hline MtC45430 & Alpha-xylosidase precursor & 1.95 & 1.11 & 1.47 \\
\hline MtC45398 & Endo-beta-1 4-D-glucanase & -1.18 & 0.96 & 0.63 \\
\hline MtC00798 & Arabinogalactan-protein precursor & -1.33 & -1.01 & -0.38 \\
\hline \multicolumn{5}{|l|}{ Cytoskeleton } \\
\hline $\mathrm{MtC} 00684$ & Tubulin/ftsz protein & -1.28 & 0.90 & 1.37 \\
\hline MtC20031 & Tubulin/ftsz protein & -1.30 & 0.76 & 1.14 \\
\hline \multicolumn{5}{|c|}{ Membrane transport } \\
\hline MtC20051.1 & Envelope calcium ATPase & -2.29 & 1.66 & 0.51 \\
\hline MtC20233 & Vacuolar ATP synthase & -2.87 & -0.61 & -0.43 \\
\hline \multicolumn{5}{|c|}{ Vesicular trafficking } \\
\hline MtC93021.1 & Importin alpha subunit (NLS receptor) & 1.23 & 0.61 & 0.75 \\
\hline \multicolumn{5}{|c|}{ Primary metabolism } \\
\hline MtC90582 & Albumin 2 & -1.92 & 0.92 & 1.44 \\
\hline MtC00680.1 & Narbonin & 1.57 & 1.81 & 1.30 \\
\hline MtC00519.2 & NADH-ubiquinone oxidoreductase & -1.32 & 0.32 & 1.16 \\
\hline MtC50697 & Blue copper protein & 1.74 & 0.82 & 0.75 \\
\hline MtC30172 & Biotin carboxyl carrier protein & -3.15 & 0.52 & 0.50 \\
\hline MtC00606 & Epimerase/dehydratase & -1.69 & -0.47 & -0.33 \\
\hline MtC93062 & NADH-plastoquinone oxidoreductase & -2.50 & -0.46 & -0.65 \\
\hline \multicolumn{5}{|c|}{ Secondary metabolism } \\
\hline MtC50990 & Cytochrome P450 & -2.03 & -0.37 & 1.17 \\
\hline MtC10905 & Squalene synthase & 1.95 & 0.20 & 0.41 \\
\hline \multicolumn{5}{|c|}{ Chromatin and DNA metabolism } \\
\hline MtC10278 & Histone $\mathrm{H} 2 \mathrm{~b}$ & -1.50 & 0.86 & 1.12 \\
\hline \multicolumn{5}{|c|}{ Gene expression and RNA metabolism } \\
\hline MtC40096 & Protein disulphide isomerase & -2.80 & 0.88 & 1.77 \\
\hline MtC30151 & WRKY-type DNA binding protein & -4.17 & 0.66 & 0.48 \\
\hline MtC92170 & MYB-related transcription activator & 1.40 & 1.85 & -1.01 \\
\hline \multicolumn{5}{|c|}{ Protein synthesis and processing } \\
\hline $\mathrm{MtC} 00024$ & 40S ribosomal protein $\mathrm{S} 11$ & 3.34 & 0.59 & 1.38 \\
\hline MtC10400 & Chaperonin CPN10 & -1.69 & 0.66 & 1.20 \\
\hline MtC93070 & Subtilisin-like serine protease & 1.01 & 0.99 & 0.42 \\
\hline $\mathrm{MtC} 00760$ & Ubiquitin-conjugating enzyme & -1.69 & -0.82 & -0.36 \\
\hline MtC40177 & Serine protease & -1.56 & 0.51 & -0.61 \\
\hline \multicolumn{5}{|c|}{ Signal transduction } \\
\hline $\mathrm{MtC} 00080$ & Calmodulin & -2.26 & -0.37 & -0.58 \\
\hline MtC20202 & Ser/Thr protein phosphatase & 1.60 & -0.42 & -0.65 \\
\hline \multicolumn{5}{|l|}{ Miscellaneous } \\
\hline MtC10112 & Peroxidase precursor & -2.75 & 1.21 & 1.27 \\
\hline MtC40023.1 & Peroxidase & 0.84 & 0.50 & 1.14 \\
\hline MtC50998 & $\mathrm{C} 2$ domain-containing protein & -1.08 & -0.64 & -1.51 \\
\hline $\mathrm{MtC} 00724.1$ & Peroxidase & -1.04 & -0.58 & -2.17 \\
\hline $\mathrm{MtC} 10717$ & Peroxidase precursor & -1.32 & 0.66 & 1.47 \\
\hline $\mathrm{MtC} 00252.2$ & Stress-inducible protein & -1.22 & 0.62 & 0.54 \\
\hline $\mathrm{MtC} 00227$ & PR10 & -1.67 & -0.19 & -1.75 \\
\hline MtC10312 & Chitinase & -2.67 & -2.10 & -2.58 \\
\hline $\mathrm{MtC} 30250$ & Stress related protein & -1.15 & -1.01 & -0.73 \\
\hline MtC00640.1 & Germin-like protein (oxalate oxidase) & 1.02 & -0.78 & -1.43 \\
\hline
\end{tabular}


Table 2 continued

Shown are only those genes where data for the AM fungi G. mosseae (Gm) and

G. intraradices $(\mathrm{Gi})$ are available (Hohnjec et al. 2005)

$M$ values $>1$ or $<-1$ (more than two times regulated) are indicated in bold

\begin{tabular}{|c|c|c|c|c|}
\hline Cluster & Description & $\mathrm{Gr}$ & $\mathrm{Gm}$ & $\mathrm{Gi}$ \\
\hline \multicolumn{5}{|c|}{ Unknown function } \\
\hline MtC00311 & - & 1.24 & 4.95 & 6.42 \\
\hline MtC93285 & Growth-related protein-like & 1.44 & 5.85 & 6.21 \\
\hline $\mathrm{MtC} 10058$ & USP domain & 1.11 & 1.05 & 2.51 \\
\hline MtC93028 & Leucine-rich repeat & 2.44 & 1.73 & 1.83 \\
\hline MtC20198 & - & -1.49 & 0.61 & 1.73 \\
\hline $\mathrm{MtC} 10256$ & - & -1.75 & 0.64 & 1.24 \\
\hline MtC40200 & Methyltransferase & -2.74 & 0.82 & 0.96 \\
\hline MtC20055 & Tumour differentially expressed protein & -1.82 & 0.48 & 0.43 \\
\hline MtC00686 & Asp/Glu rich protein & -1.77 & -0.35 & 0.36 \\
\hline MtC45607 & Basic helix-loop-helix domain & 3.44 & -0.55 & -0.31 \\
\hline MtC30081 & Phosphodiesterase & -4.62 & 0.58 & -0.80 \\
\hline MtC10195 & Lys/Glu/Ala rich protein & -1.64 & -0.49 & -1.02 \\
\hline $\mathrm{MtC} 30420$ & - & -1.15 & -2.16 & -2.15 \\
\hline MtC10662 & Lipoxygenase Lh2 domain & 3.65 & -1.49 & -2.24 \\
\hline MtC00372.1 & - & -2.21 & -0.63 & -3.22 \\
\hline MtC50619 & Aldose 1-epimerase & -1.54 & -0.85 & $-\mathbf{3 . 9 7}$ \\
\hline \multicolumn{5}{|l|}{ No homology } \\
\hline MtC91938 & - & -1.42 & 0.52 & 1.06 \\
\hline MtC91288 & - & 2.00 & -0.77 & -1.08 \\
\hline $\mathrm{MtC} 00275$ & - & 2.11 & -1.09 & -1.53 \\
\hline
\end{tabular}

analysis was carried out using the sensitive semiquantitative RT-PCR technique. For none of the genes, data were obtained in the present analysis or in the analysis by Hohnjec et al. (2005). In another analysis using M. truncatula mycorrhizal roots colonised with the AM fungi G. intraradices, G. mosseae and Scutellospora castanea (Feddermann et al. 2008) six out of ten mycorrhiza-regulated genes were only induced by $S$. castanea, but not by the two Glomus species. It is difficult to compare the analyses amongst each other, because different environmental conditions influence the outcome of the experiments. Nevertheless, general expression patterns suggest that the phylogenetic distance between AM fungal isolates is not only restricted to the morphology of spores, the mode of colonisation or the amount of phosphate which is transported from the fungus to the plant (for review, see Franken and George 2006), but is also mirrored by the plant genes which are regulated during mycorrhization.

Phytohormone-regulated transcript levels

Alterations in the homeostasis of plant hormones have been implicated in the process of mycorrhization. There are numerous reports showing that the levels of plant hormones such as cytokinin, JA, auxin, auxin-related compounds and ABA actually change upon the establishment of AM (for review, see Hause et al. 2007). Regarding JA and ABA, both phytohormones are well known for its important signalling and regulatory roles that enable plants to survive a variety of abiotic and biotic stresses (Finkelstein and Rock 2002; Wasternack 2007). To assess whether or not mycorrhizal-regulated genes could also be induced or repressed by phytohormones, non-inoculated plants were challenged $4 \mathrm{~h}$ before root sampling for RNA extraction with ABA or JA. cDNA probes synthesised from this RNA were used to hybridise Mt6kRIT arrays. Based on the same parameters as described above, 121 of 1,202 genes were induced by ABA and 205 were repressed (Table 1). Similar analyse has been carried out for example in rice and in sugarcane (Rabbani et al. 2003; Rocha et al. 2007) and numerous genes identified as responsive to abiotic stress in different plants were shown to be also regulated by ABA (for review, see Yamaguchi-Shinozaki and Shinozaki 2006). Such stress-regulated genes were found amongst the sequences showing an increased hybridisation signal on the array, but the number was not particularly high (Table S2b in Supplementary material). Comparing the ABA and G. rosea-regulated expression patterns, the overlap was very small (Table 3 ). This indicates that the increase of this phytohormone during mycorrhization is too low for a regulation of a significant number of genes or that the response is restricted to a very few cells. Nevertheless, ABA is necessary for the proper formation of arbuscules and for a sustained colonisation of the plant root as shown by the 
Table 3 Overlapping expression patterns

\begin{tabular}{lllllll}
\hline & ABA+ & ABA- & JA+ & JA- & P+ & P- \\
\hline Gr+ & $2 \%$ & $3 \%$ & $1 \%$ & $0 \%$ & $21 \%$ & $5 \%$ \\
Gr- & $4 \%$ & $3 \%$ & $6 \%$ & $13 \%$ & $1 \%$ & $31 \%$ \\
$\mathrm{ABA}+$ & & & $2 \%$ & $4 \%$ & $3 \%$ & $2 \%$ \\
$\mathrm{ABA}-$ & & & $5 \%$ & $7 \%$ & $3 \%$ & $4 \%$ \\
$\mathrm{JA}+$ & & & & & $3 \%$ & $1 \%$ \\
$\mathrm{JA}-$ & & & & & $3 \%$ & $3 \%$ \\
\hline
\end{tabular}

The table shows the percentage of gene numbers with identical regulation (induced or repressed) to the total gene numbers with significant results in two treatments

+ and - mean significantly induced or repressed by the particular treatment

analysis of AM colonisation of the tomato mutant sitiens, in which ABA levels are drastically reduced in comparison to wild-type tomato plants (Herrera-Medina et al. 2007). Interestingly, the present analysis revealed that two leghemoglobin-encoding genes showed induced transcript levels by G. rosea and ABA (Table S4 in Supplementary material). It has been suggested that leghemoglobins play a role in detoxification in mycorrhizal and nodulated roots as well as also under non-symbiotic conditions by binding nitric oxide (Vieweg et al. 2005). Since nitric oxide is involved in ABA signalling in stress responses (Ruan et al. 2004), leghemoglobin expression could be part of an auto regulatory circuit involved in the fine-tuning of the system during ABA response.

In the case of JA, Mt6kRIT macroarrays were screened and significant data were obtained for 433 genes, of which 193 seemed to be up- and 71 down-regulated (Table 1). When compared with the other treatments, a significant fraction of the induced genes putatively encodes components of secondary metabolism and stress response (Table S2c in Supplementary material). This is in accordance with the proposed function of jasmonates in the plant reaction to various stress factors (Wasternack and Hause 2002) and corresponds to data obtained from a transcriptional analysis of sugarcane roots treated with JA methyl ester (Bower et al. 2005). Stress response was also the category, where the expression patterns in mycorrhiza mostly overlapped with those in JA treated roots (Table S4 in Supplementary material). This suggests at least some of the genes involved in this reaction in mycorrhizal roots could be indirectly regulated by changes in the JA level.

$\mathrm{P}_{\mathrm{i}}$-regulated transcript levels

Mycorrhizal fungi are generally able to increase the $P_{i}$ level in plants (Bucher 2007). Additional array hybridisation experiments have therefore been carried out, in order to distinguish genes directly regulated by the AM fungus from those, which could be induced or repressed indirectly by the improved phosphate nutrition. Plants were grown in parallel to those mentioned above, but were fertilised with sufficient amounts of $\mathrm{P}_{\mathrm{i}}$. RNA was extracted and used for probe synthesis and hybridisation. Amongst the 1,221 genes with statistically significant results (Table 1), 139 showed a greater than two times induction by $\mathrm{P}_{\mathrm{i}}$ and 143 were repressed (Table S2d in Supplementary material). This was less than has been observed on Mt16kOLI1 microarrays (26 and $16 \%$; Hohnjec et al. 2005), but much more than amongst the genes identified in a mycorrhizal cDNA library ( 0.7 and 0.5\%; Liu et al. 2003). Comparison of the expression patterns revealed that amongst 218 genes, where significant data were obtained for both treatments, 21 or $31 \%$ were similarly induced or repressed in G. rosea-colonised and $\mathrm{P}_{\mathrm{i}}$-fertilised roots (Table 3). This was relatively high and contrasts the overlapping expression values of 4 or $9 \%$ found between roots fertilised with $\mathrm{P}_{\mathrm{i}}$ and roots inoculated with $G$. mosseae or G. intraradices, respectively (Hohnjec et al. 2005).

An additional experiment was carried out to analyse, whether this difference in gene expression patterns could be based on different symbiotic activities of the three AM fungi. M. truncatula seedlings were inoculated in parallel with G. mosseae, G. intraradices or G. rosea or were mock-inoculated and grown under phosphate-limiting conditions. When the mycorrhizal symbioses were fully established (60-80\% colonisation), soluble $\mathrm{P}_{\mathrm{i}}$ concentrations were measured in the shoots, since they are discussed to be mainly involved in the regulation of genes in the roots (Franco-Zorrilla et al. 2004). Comparing the $P_{i}$ concentrations in the mycorrhizal plants with the corresponding controls revealed that they were not much different in case of the two Glomus species, but showed a two-fold increase in G. rosea inoculated plants (Fig. 1a). This might be due to the fact that in plants interacting with Glomus species increased phosphate uptake was converted to biomass production, while in $G$. rosea plants this was not the case. In contrast these plants showed a slightly lower biomass than the corresponding controls (Fig. 1b) so that the same phosphate uptake resulted in the higher $\mathrm{P}_{\mathrm{i}}$ concentration. Such different mycorrhizal effects on $M$. truncatula biomass were observed before (Smith et al. 2003) and are probably based on the variations in carbohydrate drain of AM fungi in pot cultures, because they need different amounts of energy for building up their extraradical mycelium (Lerat et al. 2003). A recent study showed that Gigaspora species in general lead to higher $\mathrm{P}_{\mathrm{i}}$ concentrations in leaves of Plantago lanceolata than Glomus species do (Maherali and Klironomos 2007). In the present experiment, the higher $P_{i}$ concentrations in the shoots of $G$. rosea-colonised plants can explain the high overlap in the expression pattern with those plants which were fertilised with $\mathrm{P}_{\mathrm{i}}$ and the differences to the results obtained before with Glomus species. 

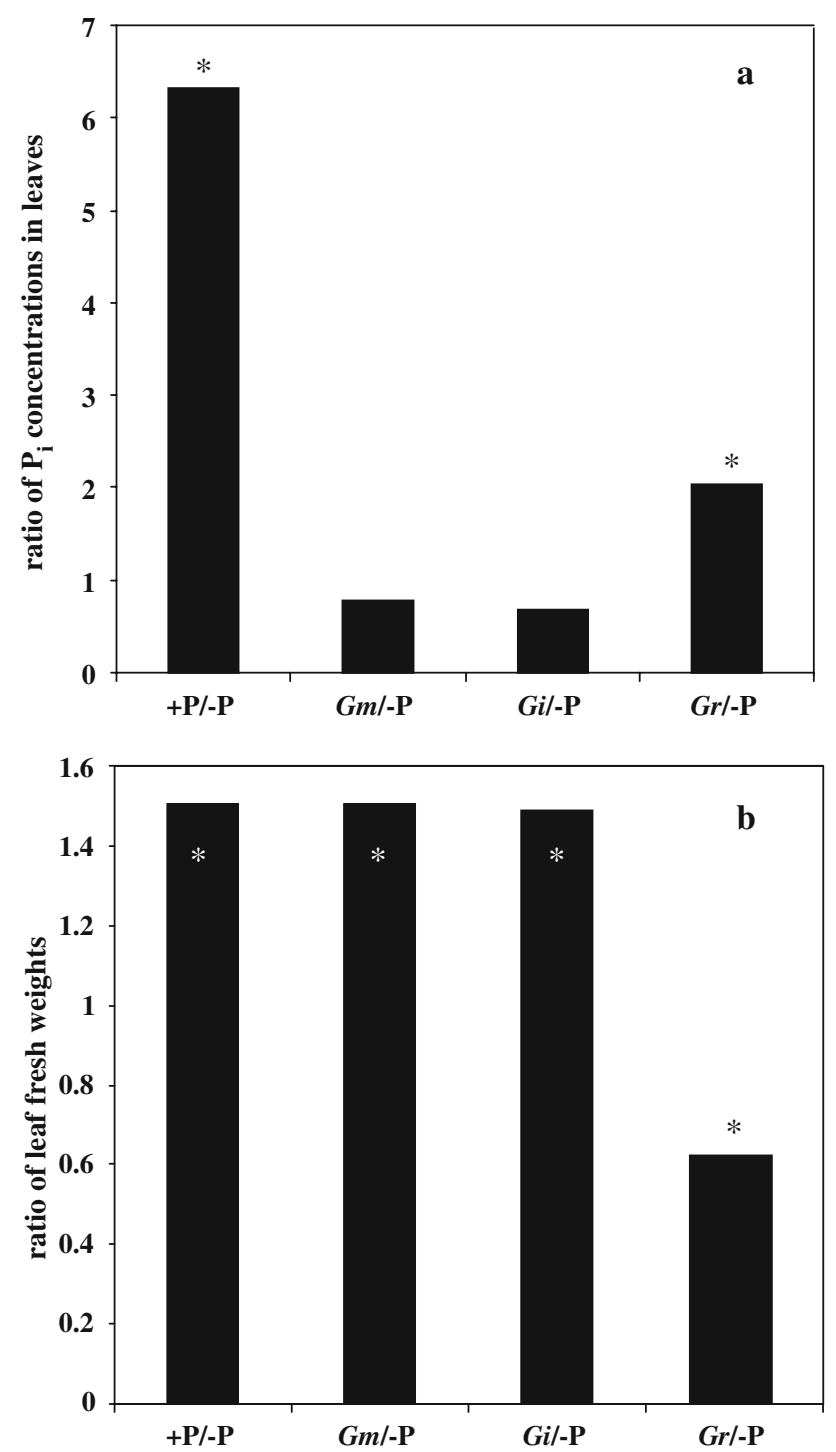

Fig. $1 \mathrm{P}_{\mathrm{i}}$ concentrations and fresh weights. Medicago truncatula plants were cultivated and fertilised with $0.13 \mathrm{mM}(-\mathrm{P})$ or $1.3 \mathrm{mM} \mathrm{P}$ $(+\mathrm{P})$ or fertilised with $0.13 \mathrm{mM} \mathrm{P}_{\mathrm{i}}$ and inoculated with the AM fungi Glomus mosseae (Gm), Glomus intraradices (Gi) and Gigaspora rosea $(G r)$. Six weeks after inoculation, soluble $\mathrm{P}_{\mathrm{i}}$ concentrations and fresh weights were measured and the ratio of the $P_{i}$ concentrations (a) and the fresh weights (b) in $1.3 \mathrm{mM} \mathrm{P}_{\mathrm{i}}$-fertilised or inoculated plants to contents in the control treatments were calculated. Significant differences are indicated by asterisks (one-way ANOVA; $P<0.05 ; n=4$ )

\section{Transcript levels of $M t P T$ genes}

To analyse whether patterns of overlapping Pi- and mycorrhiza-regulated transcript levels can be extended to genes directly involved in $\mathrm{P}_{\mathrm{i}}$ nutrition of the plants, databases were screened for cDNA sequences with homologies for phosphate transporter genes. Apart from MtPT1, MtPT2 and MtPT4, which are known from previous studies (Liu et al. 1998; Harrison et al. 2002), a number of other putative PT-encoding genes were identified. Primers were designed based on sequence alignment and used for a first non-quantitative RT-PCR experiment. Four of these putative genes showed RNA levels in mycorrhizal roots (data not shown). Full length cDNA sequences were available for MtPT3 and MtPT5 and the characterisation of these two genes was recently published (Liu et al. 2008). The other two putative genes could only be deduced from different cDNA and genomic sequences in the database. Further PCR cloning experiments revealed a sixth gene (MtPT6), while one tentative consensus (TC107305) turned out to encode only a truncated phosphate transporter. In order to analyse the phylogenetic relationship between the phosphate transporters, amino acid sequences were deduced and aligned with each other and with those from other plants (Fig. 2). This revealed that amongst the class II

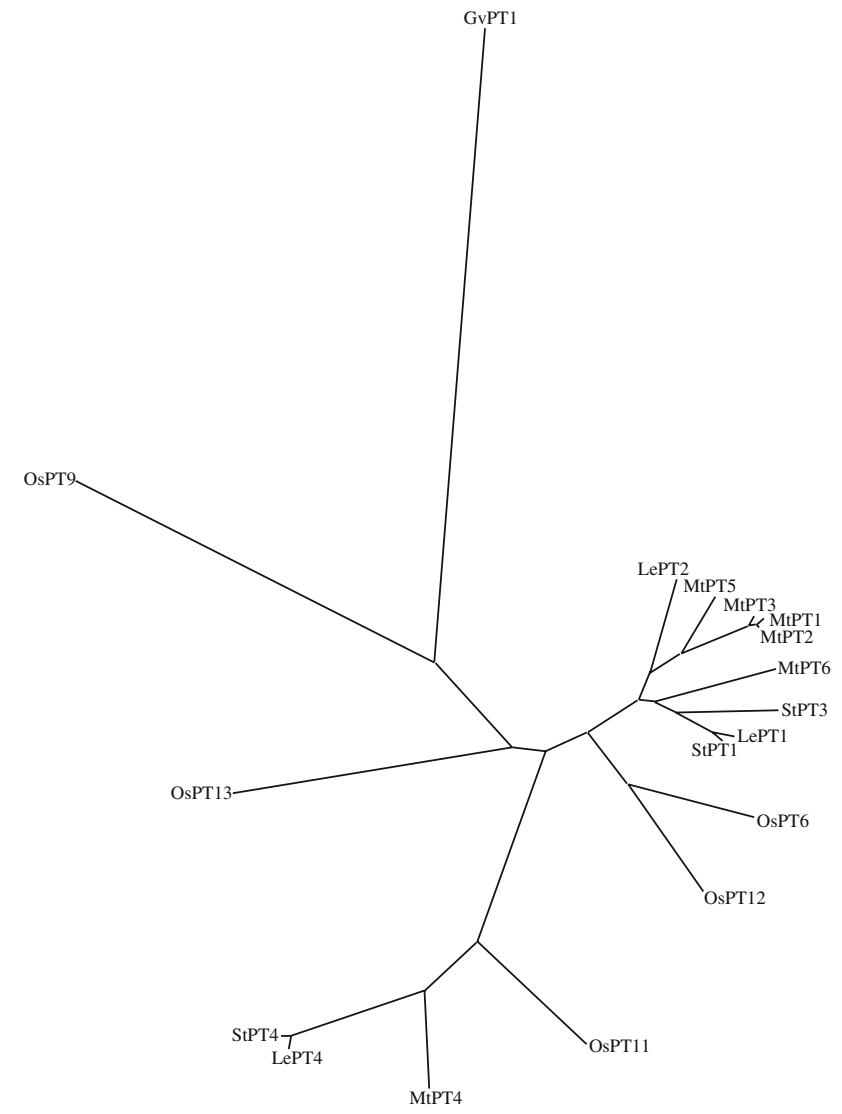

Fig. 2 Phylogenetic tree of plant phosphate transporters. Amino acid sequences of phosphate transporters from Medicago truncatula (MtPT1: AAB81346, MtPT2: AAB81347, MtPT3: ABM69110, MtPT4: AAM76744, MtPT5: ABM69111, MtPT6: CAQ42956), from tomato (LePT1: AAB82146, LePT2: AAB82147; LePT4: AAV97730), from potato (StPT1: CAA67395, StPT3: AAV97729, StPT4: AAW51149), from rice (OsPT6: AF536966, OsPT9: AF536969, OsPT11: AF536971, OsPT12: AF536972, OsPT13: AF536973) and from Glomus versiforme as outgroup (GvPT1: AAC49132) were aligned using ClustalW. Based on the alignment, phylogeny was reconstructed with the program PUZZLE and the distance tree was displayed by the program TREEVIEW 


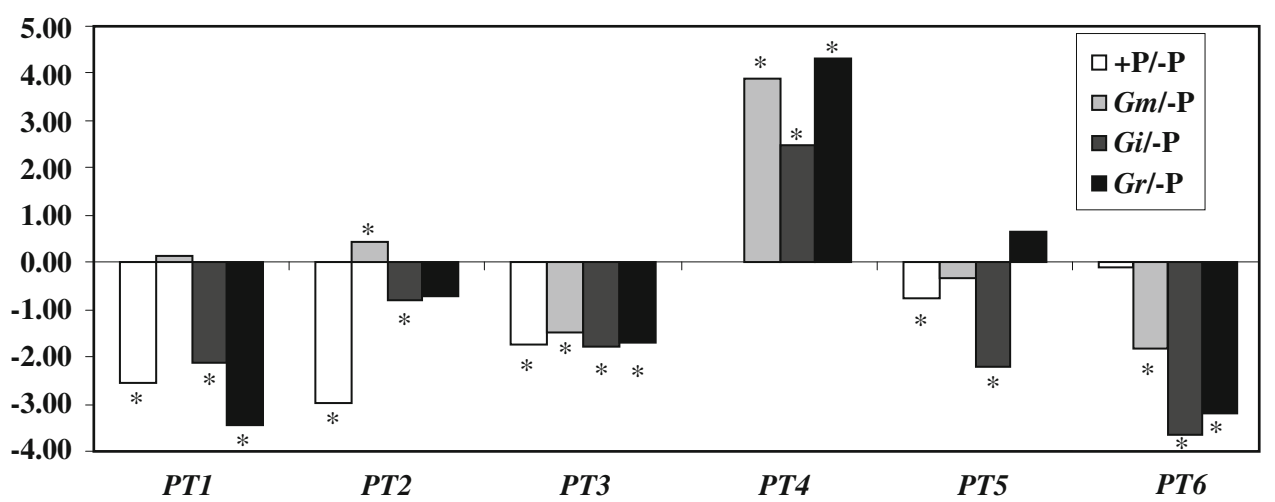

Fig. $3 M t P T$ gene regulation. RNA was extracted from roots of Medicago truncatula plants fertilised with $0.13 \mathrm{mM}(-\mathrm{P})$ or $1.3 \mathrm{mM}$ $\mathrm{P}_{\mathrm{i}}(+\mathrm{P})$ or fertilised with $0.13 \mathrm{mM} \mathrm{P}_{\mathrm{i}}$ and inoculated with the AM fungi Glomus mosseae ( $\mathrm{Gm})$, Glomus intraradices (Gi) and Gigaspora rosea $(G r)$. The RNA was used as template for real-time RT-PCR experiments using primer pairs for different phosphate transporter genes from $M$. truncatula (MtPT1-6). Results were calibrated by

of phosphate transporters (Nagy et al. 2005), MtPT1, 2, 3 and 5 group closely together, while MtPT6 occupies a branch together with StPT1 and StPT3 from potato and StPT1 from tomato. As already shown (Nagy et al. 2005), MtPT4 belongs to the class I which members are all exclusively expressed or highly up-regulated in mycorrhizal roots. Based on the sequence similarities, all phosphate transporter genes are probably located at the plasma membrane and this has been shown for at least some of them (Liu et al. 2008).

Based on the sequences of the six different transporter genes, primer pairs were designed and used for quantitative real-time RT-PCR experiments using as template RNA extracts from roots fertilised with high amounts of $\mathrm{P}_{\mathrm{i}}$ $\left(1.3 \mathrm{mM} \mathrm{P}_{\mathrm{i}}\right)$ or inoculated with $G$. rosea, G. mosseae or $G$. intraradices (60-80\% mycorrhization) or from control roots of this experiment $\left(0.13 \mathrm{mM} \mathrm{P}_{\mathrm{i}}\right)$. The results were calibrated by the levels of the constitutively expressed MtTef1 gene and $M$ values were calculated for the ratios of the relative transcript levels in the roots fertilised with $1.3 \mathrm{mM} \mathrm{P}_{\mathrm{i}}$ or inoculated with the different AM fungi to the values obtained from the $0.13 \mathrm{mM} \mathrm{P}_{\mathrm{i}}$ controls (Fig. 3). This revealed that MtPT4 is only regulated by mycorrhization as it has been shown many times before and that this is true for all three AM fungi used in the experiment. The expression is specific for cells harbouring fungal arbuscules and cannot be seen in any other tissue (Harrison et al. 2002) and the gene is essential for the function of the symbiosis (Javot et al. 2007). MtPTl is down-regulated in roots fertilised with $\mathrm{P}_{\mathrm{i}}$ or colonised by $G$. intraradices and $G$. rosea (Fig. 3). MtPT1 is root epidermis-specific expressed (Xiao et al. 2006) and therefore likely to be responsible for $P_{i}$ uptake from the soil. Interestingly, colonisation by G. mosseae does not lead to a repressed transcript levels of the gene values obtained for the constitutively expressed gene MtTef1. The graphs show $M$ values for the ratios of the expression in $+\mathrm{P}$ roots (white columns), Gm mycorrhizas (light grey columns), Gi mycorrhizas (dark grey columns) and $\mathrm{Gr}$ mycorrhizas (black columns) compared to the expression in $-\mathrm{P}$ roots. Significant differences (oneway ANOVA; $P<0.05 ; n=9$ ) are indicated with an asterisk

confirming the result obtained before (Hohnjec et al. 2005). MtPT2 is significantly down-regulated by high $\mathrm{P}_{\mathrm{i}}$ only (Fig. 3). MtPT2 promoter activity has been located in the vascular cylinder (Xiao et al. 2006). Therefore, the activity of the resulting protein might be also required in a mycorrhizal root explaining why the expression level is not very much affected in the symbiosis. The gene MtPT3 is downregulated by $\mathrm{P}_{\mathrm{i}}$ and by all three AM fungi (Fig. 3), which is consistent with the results obtained by Liu et al. (2008). MtPT5 is significantly repressed only in roots colonised by $G$. intraradices, but not in those containing hyphae of G. mosseae and G. rosea (Fig. 3). Inoculation with G. versiforme did also not lead to a reduced RNA level of MtPT5 and it was shown that the gene is expressed in all parts of the root except the vascular tissues, but including the cortex of the colonised region (Liu et al. 2008). Concerning regulation by $\mathrm{P}_{\mathrm{i}}$ contradictory results were obtained. Growing plants in a substrate under low or high $\mathrm{P}_{\mathrm{i}}$ conditions only slightly influences MtPT5 (Fig. 3), but resupplying the mineral element to roots in a nutrient solution immediately leads to a sharp decrease of MtPt5 RNA (Liu et al. 2008). This indicates that the down-regulation of the gene by $\mathrm{P}_{\mathrm{i}}$ is only transient. MtPT6 is only regulated by the three AM fungi (Fig. 3). This clearly supports the suggestion by Liu et al. (2008) that the down-regulation of PTencoding genes in mycorrhizal roots is not mediated by an increased $\mathrm{P}_{\mathrm{i}}$ content in the plant.

\section{Conclusion}

Comparison of gene expression in roots colonised with the AM fungus $G$. rosea and treated with the two phytohormones ABA and JA revealed only a very small number of 
genes with a common pattern of regulation. If mycorrhizaregulated expression occurs indirectly via changes in phytohormone levels, this seems to be only true for a very few genes. A much higher overlap was detected with the expression in $\mathrm{P}_{\mathrm{i}}$-fertilised roots and this is different to results obtained before with Glomus species. This is probably due to the higher $\mathrm{P}_{\mathrm{i}}$ concentration in the leaves of the plants colonised by $G$. rosea. It indicates that at least a number of these genes are not directly regulated by the AM fungus $G$. rosea, but rather indirectly by the better supply with the mineral nutrient. Variations in the expression patterns between the three AM fungi were also observed amongst the phosphate transporter gene family of M. truncatula. The fungi induce down-regulation of various number of PT-encoding genes with $G$. intraradices repressing most (MtPT1, 3, 5 and 6 ) and G. mosseae least genes (MtPT3 and 6), while G. rosea occupies a middle position down-regulating MtPTl, 3 and 6. Data for G. mosseae are not available, but the analysis of phosphate transport in tomato via the mycorrhizal or the direct uptake pathway showed that $G$. intraradices suppresses nearly totally the direct uptake of phosphate by the root itself and G. rosea does not (Smith et al. 2004). It has to be shown in future experiments, whether this is also true for M. truncatula and how the differential expression of the PT-encoding genes in $M$. truncatula is involved in such a phenomenon. The present results together with the finding that MtPT5 is expressed in root hairs and the epidermis and encodes a low affinity phosphate transporter (Liu et al. 2008) indicates that this gene might be important for the direct uptake pathway.

Acknowledgments The work was carried out in frame of the MolMyk programme funded by the German research foundation (DFG SPP 1084). The visit of Wenbing Guo at the IGZ was financed by the German Federal Ministry of Food, Agriculture and Consumer Protection (BMVEL) and by the Chinese Ministry of Agriculture and Ministry of Science and Technology. Helge Küster acknowledges financial support from the International Graduate School in Bioinformatics and Genome Research.

\section{References}

Balestrini R, Lanfranco L (2006) Fungal and plant gene expression in arbuscular mycorrhizal symbiosis. Mycorrhiza 16:509-524

Bauer D, Müller H, Reich J, Riedel H, Ahrenkiel V, Warthoe P, Strauss M (1993) Identification of differentially expressed mRNA species by an improved display technique (DDRT-PCR). Nucl Acid Res 21:4272-4280

Borowicz VA (2001) Do arbuscular mycorrhizal fungi alter plantpathogen relations? Ecology 82:3057-3068

Bower NI, Casu RE, Maclean DJ, Reverter A, Chapman SC, Manners JM (2005) Transcriptional response of sugarcane roots to methyl jasmonate. Plant Sci 168:761-772

Bucher M (2007) Functional biology of plant phosphate uptake at root and mycorrhiza interfaces. New Phytol 173:11-26
Burleigh SH, Cavagnaro T, Jakobsen I (2002) Functional diversity of arbuscular mycorrhizas extends to the expression of plant genes involved in P nutrition. J Exp Bot 53:1593-1601

Cavagnaro TR, Smith FA, Smith SE, Jakobsen I (2005) Functional diversity in arbuscular mycorrhizas: exploitation of soil patches with different phosphate enrichment differs among fungal species. Plant Cell Environ 28:642-650

Dondrup M, Goesmann A, Bartels D, Kalinowski J, Krause L, Linke B, Rupp O, Sczyrba A, Puhler A, Meyer F (2003) EMMA: a platform for consistent storage and efficient analysis of microarray data. J Biotechnol 106:135-146

Feddermann N, Boller T, Salzer P, Elfstrand S, Wiemken A, Elfstrand M (2008) Medicago truncatula shows distinct patterns of mycorrhiza-related gene expression after inoculation with three different arbuscular mycorrhizal fungi. Planta 227:671-680

Finkelstein RR, Rock CD (2002) Abscisic acid biosynthesis and response. In: Somerville CR, Meyerowitz EM (eds) The Arabidopsis book. American Society of Plant Biologists, Rockville, pp 1-48

Franco-Zorrilla JM, Gonzalez E, Bustos R, Linhares F, Leyva A, Paz-Ares J (2004) The transcriptional control of plant responses to phosphate limitation. J Exp Bot 55:285-293

Franken P, George E (2006) Diversity of arbuscular mycorrhizal fungi. In: Benckiser G, Schnell S (eds) Biodiversity in agricultural production systems. CRC Press, Boca Raton, pp 189-203

Gianinazzi-Pearson V, Dumas-Gaudot E, Gollotte A, Tahhiri-Alaoui A, Gianinazzi S (1996) Cellular and molecular defence-related root response to invasion by arbuscular mycorrhizal fungi. New Phytol 133:45-57

Gohre V, Paszkowski U (2006) Contribution of the arbuscular mycorrhizal symbiosis to heavy metal phytoremediation. Planta 223:1115-1122

Grunwald U, Nyamsuren O, Tarnasloukht M, Lapopin L, Becker A, Mann P, Gianinazzi-Pearson V, Krajinski F, Franken P (2004) Identification of mycorrhiza-regulated genes with arbuscule development-related expression profile. Plant Mol Biol 55:553-566

Guimil S, Chang HS, Zhu T, Sesma A, Osbourn A, Roux C, Ionnidis V, Oakeley EJ, Docquier M, Descombes P, Briggs SP, Paszkowski U (2005) Comparative transcriptomics of rice reveals an ancient pattern of response to microbial colonization. Proc Natl Acad Sci USA 102:8066-8070

Harrison MJ, Dewbre GR, Liu JY (2002) A phosphate transporter from Medicago truncatula involved in the acquisition of phosphate released by arbuscular mycorrhizal fungi. Plant Cell 14:2413-2429

Hause B, Mrosk C, Isayenkov S, Strack D (2007) Jasmonates in arbuscular mycorrhizal interactions. Phytochemistry 68:101-110

Herrera-Medina MJ, Steinkellner S, Vierheilig H, Ocampo Bote JA, Garcia Garrido JM (2007) Abscisic acid determines arbuscule development and functionality in the tomato arbuscular mycorrhiza. New Phytol 175:554-564

Hewitt EJ (1966) Sand and water culture methods. Tech. Comm. 22 (2nd revised). Commonwealth Agricultural Bureau, London, pp 430-434

Hohnjec N, Vieweg ME, Puhler A, Becker A, Kuster H (2005) Overlaps in the transcriptional profiles of Medicago truncatula roots inoculated with two different Glomus fungi provide insights into the genetic program activated during arbuscular mycorrhiza. Plant Physiol 137:1283-1301

Isayenkov S, Mrosk C, Stenzel I, Strack D, Hause B (2005) Suppression of allene oxide cyclase in hairy roots of Medicago truncatula reduces jasmonate levels and the degree of mycorrhization with Glomus intraradices. Plant Physiol 139:1401-1410

Javot H, Penmetsa RV, Terzaghi N, Cook DR, Harrison MJ (2007) A Medicago truncatula phosphate transporter indispensable for the arbuscular mycorrhizal symbiosis. Proc Natl Acad Sci USA 104:1720-1725 
Krajinski F, Hause B, Gianinazzi-Pearson V, Franken P (2002) MtHA1, a plasma membrane $\mathrm{H}^{+}$-ATPase gene from Medicago truncatula, shows arbuscule-specific induced expression. Plant Biol 4:754-761

Küster H, Hohnjec N, Krajinski F, El Yahyaoui F, Manthey K, Gouzy J, Dondrup M, Meyer F, Kalinowski J, Brechenmacher L, Van Tuinen D, Gianinazzi-Pearson V, Puhler A, Gamas P, Becker A (2004) Construction and validation of cDNA-based Mt6 k-RIT macro- and microarrays to explore root endosymbioses in the model legume Medicago truncatula. J Biotechnol 108:95-113

Lerat S, Lapointe L, Gutjahr S, Piche Y, Vierheilig H (2003) Carbon partitioning in a split-root system of arbuscular mycorrhizal plants is fungal and plant species dependent. New Phytol 157:589-595

Li HY, Yang GD, Shu HR, Yang YT, Ye BX, Nishida I, Zheng CC (2006) Colonization by the arbuscular mycorrhizal fungus Glomus versiforme induces a defense response against the rootknot nematode Meloidogyne incognita in the grapevine (Vitis amurensis Rupr.), which includes transcriptional activation of the class III chitinase gene VCH3. Plant Cell Physiol 47:154-163

Liu J, Trieu AT, Blayloock LA, Harrison MJ (1998) Cloning and characterization of two phosphate transporters from Medicago truncatula: root regulation in response to phosphate and to colonization by arbuscular mycorrhizal fungi. Mol Plant Microbe Interact $11: 14-22$

Liu J, Blaylock LA, Endre G, Cho J, Town CD, VandenBosch KA, Harrison MJ (2003) Transcript profiling coupled with spatial expression analyses reveals genes involved in distinct developmental stages of an arbuscular mycorrhizal symbiosis. Plant Cell $15: 2106-2123$

Liu J, Maldonado-Mendoza I, Lopez-Meyer M, Cheung F, Town CD, Harrison MJ (2007) Arbuscular mycorrhizal symbiosis is accompanied by local and systemic alterations in gene expression and an increase in disease resistance in the shoots. Plant J 50:529-544

Liu J, Versaw WK, Pumplin N, Gomez SK, Blaylock LA, Harrison MJ (2008) Closely related members of the Medicago truncatula PHT1 phosphate transporter gene family encode phosphate transporters with distinct biochemical activities. J Biol Chem 283:24673-24681

Ludwig-Muller J (2000) Hormonal balance in plants during colonization by mycorrhizal fungi. In: Kapulnik Y, Douds DD Jr (eds) Arbuscular mycorrhizas: physiology and function. Kluwer, Netherlands, pp 263-285

Maeda D, Ashida K, Iguchi K, Chechetka SA, Hijikata A, Okusako Y, Deguchi Y, Izui K, Hata S (2006) Knockdown of an arbuscular mycorrhiza-inducible phosphate transporter gene of Lotus japonicus suppresses mutualistic symbiosis. Plant Cell Physiol 47:807817

Maherali H, Klironomos JN (2007) Influence of phylogeny on fungal community assembly and ecosystem functioning. Science 316:1746-1748

Maldonado-Mendoza IE, Dewbre GR, Blaylock L, Harrison MJ (2005) Expression of a xyloglucan endotransglucosylase/hydrolase gene, Mt-XTH1, from Medicago truncatula is induced systemically in mycorrhizal roots. Gene 345:191-197

Manthey K, Krajinski F, Hohnjec N, Firnhaber C, Puhler A, Perlick AM, Kuster H (2004) Transcriptome profiling in root nodules and arbuscular mycorrhiza identifies a collection of novel genes induced during Medicago truncatula root endosymbioses. Mol Plant Microbe Interact 17:1063-1077

Massoumou M, van Tuinen D, Chatagnier O, Arnould C, Brechenmacher L, Sanchez L, Selim S, Gianinazzi S, Gianinazzi-Pearson V (2007) Medicago truncatula gene responses specific to arbuscular mycorrhiza interactions with different species and genera of Glomeromycota. Mycorrhiza 17:223-234
Murphy J, Riley JP (1962) A modified single solution method for the determination of phosphate in natural waters. Anal Chim Acta 27:31-36

Nagy R, Karandashov V, Chague W, Kalinkevich K, Tamasloukht M, Xu GH, Jakobsen I, Levy AA, Amrhein N, Bucher M (2005) The characterization of novel mycorrhiza-specific phosphate transporters from Lycopersicon esculentum and Solanum tuberosum uncovers functional redundancy in symbiotic phosphate transport in solanaceous species. Plant $\mathrm{J} 42: 236-250$

Newman EI, Reddell P (1987) The distribution of mycorrhizas among families of vascular plants. New Phytol 106:745-751

Page RDM (1996) TREEVIEW: an application to display phylogenetic trees on personal computers. Comp Appl Biosci 12:357-358

Parniske M (2000) Intracellular accommodation of microbes by plants: a common developmental program for symbiosis and disease? Curr Opin Plant Biol 3:320-328

Rabbani MA, Maruyama K, Abe H, Khan MA, Katsura K, Ito Y, Yoshiwara K, Seki M, Shinozaki K, Yamaguchi-Shinozaki K (2003) Monitoring expression profiles of rice genes under cold, drought, and high-salinity stresses and abscisic acid application using cDNA microarray and RNA get-blot analyses. Plant Physiol 133:1755-1767

Rausch C, Daram P, Brunner S, Jansa J, Laloi M, Leggewie G, Amrhein N, Bucher M (2001) A phosphate transporter expressed in arbuscule-containing cells in potato. Nature 414:462-466

Rocha FR, Papini-Terzi FS, Nishiyama MY, Vencio RZN, Vicentini R, Duarte RDC, de Rosa VE, Vinagre F, Barsalobres C, Medeiros AH, Rodrigues FA, Ulian EC, Zingaretti SM, Galbiatti JA, Almeida RS, Figueira AVO, Hemerly AS, Silva-Filho MC, Menossi M and Souza GM (2007) Signal transduction-related responses to phytohormones and environmental challenges in sugarcane. BMC Genomics 8. Ref ID: 4603

Ruan HH, Shen WB, Xu LL (2004) Nitric oxide involved in the abscisic acid induced proline accumulation in wheat seedling leaves under salt stress. Acta Bot Sin 46:1307-1315

Ruiz-Lozano JM (2003) Arbuscular mycorrhizal symbiosis and alleviation of osmotic stress. New perspectives for molecular studies. Mycorrhiza 13:309-317

Schüßler A, Schwarzott D, Walker C (2001) A new fungal phylum, the Glomeromycota: phylogeny and evolution. Mycol Res 105:14131421

Smith SE, Read DJ (1997) Mycorrhizal symbiosis. Academic Press, London

Smith SE, Smith FA, Jakobsen I (2003) Mycorrhizal fungi can dominate phosphate supply to plants irrespective of growth responses. Plant Physiol 133:16-20

Smith SE, Smith FA, Jakobsen I (2004) Functional diversity in arbuscular mycorrhizal (AM) symbioses: the contribution of the mycorrhizal $\mathrm{P}$ uptake pathway is not correlated with mycorrhizal responses in growth or total P uptake. New Phytol 162:511-524

Strimmer K, von Haeseler A (1996) Quartet puzzling: a quartet maximum likelihood method for reconstructing tree topologies. Mol Biol Evol 13:964-969

Thompson JD, Higgins DG, Gibson TJ (1994) CLUSTAL W: improving the sensitivity of progressive multiple sequence alignment through sequence weighting, position-specific gap penalties and weight matrix choice. Nucl Acids Res 22:4673-4680

Trouvelot A, Kough JL, Gianinazzi-Pearson V (1986) Mesure du taux de mycorhization VA d'un système radiculaire. Recherche des méthodes d'estimation ayant une signification fonctionnelle. In: Gianinazzi-Pearson V, Gianinazzi S (eds) The mycorrhizae: physiology and genetics. INRA Presse, Paris, pp 217-221

Van Rhijn P, Fang Y, Galili S, Shaul O, Atzmon N, Wininger S, Eshed Y, Lum M, Li Y, To V, Fujishige N, Kapulnik Y, Hirsch AM (1997) Expression of early nodulin genes in alfalfa mycorrhizae indicates that signal transduction pathways used in 
forming arbuscular mycorrhizae and rhizobium-induced nodules may be conserved. Proc Natl Acad Sci USA 94:5467-5472

Vieweg MF, Hohnjec N, Kuster H (2005) Two genes encoding different truncated hemoglobins are regulated during root nodule and arbuscular mycorrhiza symbioses of Medicago truncatula. Planta 220:757-766

Wasternack C (2007) Jasmonates: an update on biosynthesis, signal transduction and action in plant stress response, growth and development. Ann Bot 100:681-697

Wasternack C, Hause B (2002) Jasmonates and octadecanoids: signals in plant stress responses and development. Prog Nucleic Acid Res Mol Biol 72:165-221
Wulf A, Manthey K, Doll J, Perlick A, Franken P, Linke B, Meyer F, Küster H, Krajinski F (2003) Detection of highly specific transcriptional changes of the model plant Medicago truncatula in response to arbuscular mycorrhiza development. Mol Plant Microbe Interact 16:306-314

Xiao K, Liu J, Dewbre G, Harrison M, Wang ZY (2006) Isolation and characterization of root-specific phosphate transporter promoters from Medicago truncatula. Plant Biol 8:439-449

Yamaguchi-Shinozaki K, Shinozaki K (2006) Transcriptional regulatory networks in cellular responses and tolerance to dehydration and cold stresses. Annu Rev Plant Biol 57:781-803 